\title{
MANAGEMENT OF SALAFIYAH ISLAMIC BOARDING SCHOOL TOWARDS QUALITY ENHANCEMENT OF FORMAL EDUCATION INSTITUTION IN THE DIGITAL ERA
}

Nur Efendi ${ }^{1}$, Ahmad Qolfathiriyus ${ }^{2}$

IAIN Tulungagung,Email: E-mail: nurefendi2016@gmail.com

\begin{abstract}
This research is set to clarify the importance of technology in the Salafiyah Islamic boarding school in Tulungagung. It is focused on the management of the Salafiyah Islamic boarding school based on the functions of management, namely planning, implementing, and evaluating in facing educational competition in the digital age. The research method is descriptive qualitative using purposive and snowball sampling. The researchers select 3 internal stakeholders and 9 external stakeholders. The results reveal that: 1) planning function of management is categorized into good criteria by preparing facilities and infrastructure as well as professional teaching staff; 2) implementation function of management can integrate the boarding school curriculum with the modern education curriculum; 3 ) evaluation function of management is conducted by practicing various sciences in the world and the hereafter, mastering science and technology as well as faith and piety. Regarding these results, the Salafiyah Islamic boarding school requires formal education as a foundation of life to compete in this disruption era.
\end{abstract}

Keywords

Digital Era, Formal Education, Management, Salafiyah Islamic Boarding School.

Article Received: 18 October 2020, Revised: 3 November 2020, Accepted: 24 December 2020

\section{Introduction}

Islamic boarding school is the oldest educational institution that becomes one of the main characteristics of education in Indonesia (Van Bruinessen, 1995). Islamic boarding schools participate in instilling a sense of nationalism into Indonesian people, educating the nation, maintaining Islamic traditions, and transmitting Islamic religious knowledge into people's lives (Fatmawati, 2018). Learning in Islamic boarding schools is carried out in mosques taught by kyai. It studies traditional literature in the form of learning classic books that are known as kitab kuning (Arabic bare book). The teaching and learning process employs traditional structures and methods, namely: wetonan, sorogan, bandongan muzara'ah, memorizing without knowing modern learning methods (Fuadah\&Sanusi, 2017). These are the characteristic of learning model of the salafiyah Islamic boarding school.

Based on the explanation, education in the Salafiyah Islamic boarding school only potentially educate and shape the santri to become prospective scholars and produce an expert in the field of Islamic religion without having expertise in other fields related to formal education. Whereas all parties must be actively involved in character education, towards a civilized and dignified Indonesia, starting from the level of individuals, families, communities, formal educational institutions, national leaders, religious leaders, and community leaders (Sukardi, 2016).

Furthermore, with the rapid development of the time, salafiyah Islamic boarding schools should not only be silent or insensitive, but also improve themselves in bringing up creative ideas to realize the spirit of education by seeing charismatic pedagogy, strict rules, harsh conditions, and providing scarce learning resources as truth regimes and the knowledge as life experiences for santri (Nilan, 2009).

If the industry requires expertise in the field of Islamic religion, then graduates of Islamic boarding schools will be prominent to the others. However, nowadays the needed scholars are not only limited to the expertise of Islamic sciences, but also professional quality expertise. Therefore, Islamic boarding schools must carry out certain policies in terms of developing modern education (Latif, 2019). Currently, society can observe the position, goals, functions, and future directions of 
the Islamic boarding school. The society also considers that Islamic boarding school only creates scholars with ability in Islamic perspective and ignores abilities needed by the industry (Stiawan\&Toharin, 2015). This view makes Salafiyah Islamic boarding schools increasingly abandoned by stakeholders. Thus, it is very necessary to increase the management system of an Islamic boarding school.

The progress of the formal education system in the salafiyah boarding school is very important. Salafiyah Islamic boarding schools which tend to have their ideals and philosophies will be considered good by the stakeholder. The school system organizes educational relationships that force managers to adhere to static internal logic despite the existence of significant changes outside the educational scope (Tarrago\&Wilson, 2010). Records play an important role in getting effective school management, that is, if records are not managed properly, the school management function will be problematic (Gama, 2010). Therefore, the main figures in the Salafiyah Islamic boarding school must understand management comprehensively with a variety of management functions.

According to George R. Terry, there are management functions with 5 combinations to achieve the goals of a program and activity. The first management function, combination A consists of planning, organizing, providing encouragement, and supervision. The second management function, combination $\mathrm{B}$ consists of planning, organizing, motivating, and monitoring. The third management function, combination $\mathrm{C}$ consists of planning, organizing, staffing, giving direction, and supervision. The fourth management function, combination D consists of planning, organizing, staffing, giving direction, supervision, innovation, and giving a role. The fifth management function, combination $E$ consists of planning, organizing, motivating, monitoring, and coordinating. Based on the five combinations, it can be filtered into three main functions of management, namely planning, implementing, and assigning roles (Terry, 2009). It is strengthened by William A. Shcrode and Dan
Voice, Jr. that state management functions include planning, implementation, and evaluation (Sukirman, 2006). Based on the explanation above, the conclusion can be drawn that the management function includes planning, implementation, and evaluation.

Changing the salafiyah boarding school system into a modern one that has formal education facilities is not an easy thing. This is because the Salafiyah Islamic boarding school has idealism and philosophy which becomes its trademark since ancient times. In the context of religion, a moderate attitude is interpreted as a choice to have perspective, attitude, and behavior in extreme choices. At the same time, religious extremism is a way of looking, attitudes, and behavior beyond the limits of moderation in religious understanding and practice (Mehran, 2003). Educators also act as motivators to increase the awareness of students to get pleasure in participating in the education process at Salafiyah Islamic Boarding School (Rafidah et al., 2019). If these changes are made, this can make policy uncertainty from the leaders of Islamic boarding schools and result in shifts and changes that are very drastic by mixing pure Islamic sciences with general science. This makes the existence of some boarding schools lost the tradition of Islamic education in the past.

Along with the industrialization era, boarding schools have a problem in determining the curriculum, whether it must be integrated with current demands, or it must preserve its Islamic tradition by actualizing their existence amidst the demands of society (Wang\&Yaqing, 2018). The leaders of Islamic boarding schools develop and instill religious values into daily life and formulate them in the present context. Without these efforts, these values will only be a symbol of formality in attitude and behavior (Salahuddin, 2017). This makes the role of the management of boarding school leaders very important so that the two choices can still go hand in hand without destroying each other.

In Behaghel's study, only strong students who obtain advantages from an Islamic boarding school after they adapt to their new environment 
(Behaghel et al., 2017). This is the same as that faced by several boarding schools in Tulungagung. The times are very fast and the competition of life is multi-complicated along with changes in society in various aspects of life. This makes Islamic boarding schools in Tulungagung increasingly improve themselves in applying the formal education system in the scope of Islamic boarding schools.

Regarding the explanation above, the researcher is interested to investigate comprehensively related to the progress of the Salafiyah Islamic boarding school in Tulungagung. Therefore, this study aims at determining the current social changes, the existing education system, and the applied management to several salafiyah Islamic boarding schools in Tulungagung in facing social change in the digital age.

\section{Methodology}

This is a case study with a descriptive qualitative approach. According to Sugiyono, the qualitative research method is a research method that intended to examine natural conditions of objects where the researcher is a key instrument (Sugiyono, 2016). This research is focused on the management of Islamic boarding schools and examines the limitations of the management of salafiyah boarding schools in Tulungagung in facing educational competition in the digital age.

The survey model is conducted to collect information data about large populations by collecting relatively smaller samples. This model provides the opportunity for researchers to collect data from populations to determine the status of the population concerning one or more variables (Gay, 1987). Based on this method, three salafiyah Islamic boarding schools in Tulungagung are considered to be research samples. These are Hidayatul Mubtadin Ngunut, Ma'dinul Ulum Campurdarat, and Panggung salafiyah Islamic boarding school.

Purposive sampling is employed as a sampling technique. According to Sugiyono, purposive sampling is a data source sampling technique with certain considerations (Sugiyono, 2013). This particular consideration is for choosing a particular subject that is considered the most suitable for the Salafiyah Islamic boarding school. The subject of this study is also referred to as a key informant. Thus, the research subjects taken are 3 main figures of the Salafiyah Islamic Boarding School as internal stakeholders, 3 parents of the students from the Salafiyah Islamic Boarding School, 3 students from the Salafiyah Islamic Boarding School, and 3 communities around the Salafiyah Islamic Boarding School as external stakeholders.

Moreover, snowball sampling is performed as a reinforcement of the information obtained. According to Budiyono, the snowball sampling technique is a technique where the source of research data increases a lot over time. The selection of sources at the first stage (some people can be chosen) is done based on certain considerations. When the information from the first source is inadequate, the second source will increase, and so on. The addition of sources will stop if the obtained information is already fulfilled (Budiyono, 2017).

In collecting the data, the researcher employs interviews, observation, and analyzing documents. Data collection instruments include research notes, voice recording devices, and cameras. The results of interviews and field notes that have been collected are carried out into transcripts and coding. The data analysis technique is the interactive model of Miles and Huberman, namely: 1) reducing data, 2) presenting data, and 3) drawing conclusions or verification (Qolfathiriyus et al., 2019). Triangulation of sources, observation weaving, and peer analysis is intended to validate the data.

Results

The research subjects answer questions in the interview related to the management of the Salafiyah Islamic boarding school and the progress of formal educational institutions in the digital age. The following are some descriptions of verbal transcripts by internal and external stakeholders.

\section{Internal Stakeholders}

Based on the results of a survey, three Salafiyah Islamic boarding schools have formal 
institutions as internal stakeholders. Thus, 3 main figures are taken from these three Salafiyah Islamic boarding schools. The function of this interview is to find out the management of Salafiyah Islamic boarding school and the progress for a formal education institution. This interview includes the planning, implementation, and evaluation of salafiyah boarding school management towards quality enhancement of formal education in the digital age. Coding is given to the three main characters. The main figure at Hidayatul Mubtadiin Ngunut uses Subject KP1 as a code. The main figure at Ma'dinul Ulum uses Subject KP2 as a code. The main figure at Panggung Tulungagung uses Subject KP3 as a code.

a. Planning function of Management

In the planning function, the results of interviews among the internal stakeholders have the same opinion, which is the application of management is very important. The subject KP1 reveals, "It is very important because the implementation process towards quality enhancement of formal education can run well according to the plans that have been made. So, without implementing management, all activities can be hampered". This is also reinforced by the statement of Subject KP2 which states that when the boarding school implements management, all processes of activities in promoting formal education can run well, besides, management can also affect the development of individual and group capacity of teaching staff here.

In implementing a function, the main figures have performed well for formal institutions. Subject KP1 said, "The implementation can run well, this is because the learning process has been implemented from the web. Several classes have been facilitated by the projector and it will be improved in the future to facilitate each class, computer space is also quite adequate, besides that blended learning is now well implemented ". The implementation function has also been carried out by other figures. The KP3 subject said that formal education in the scope of Islamic boarding schools could progress well so what has to be prepared is technology to support the learning process, such as computers, wifi, learning applications, projector media, and others.

There are some obstacles to the implementation function. The obstacles are revealed by Subject KP2, "To advance formal education in this boarding school, there are quite a variety of obstacles. For example, opponents state that the existence of formal education in Islamic boarding school can eliminate the tradition that has existed since ancient times, limited funds to prepare facilities and infrastructure. Even to get professional educators is also difficult ". Obstacles also occur in another scope. The subject KP3 reveals that the most important obstacle is to provide funds for adequate infrastructure, looking for educators who mastered the science of technology.

Based on these obstacles, the main characters have a good method and strategy. The subject KP1 said that the key is patience in carrying out the plans that have been prepared, patience in providing knowledge and explanations to those who do not agree with this program, patience in educating students, and believing that doing something with good intentions must always have a solution. The same thing is done by the other main characters. The subject of KP2 said, "The way is implementing proper and mature management and then applying that management with patience. Because solving these obstacles also requires a long time. It can be achieved by establishing good relations among the society, the parents of the students, the educators as well as the board administrators."

b. implementation function of Management

The management of formal education that has been applied to salafiyah Islamic boarding schools is almost certainly good. This has been implemented in 3 salafiyah 
Islamic boarding schools that have formal institutions. KP1 subject said, "the implemented management is education management including Islamic boarding school curriculum, modern Islamic boarding school curriculum, teaching system (memorization method, weton or bandongan method, sorogan method), financial system. If the Islamic boarding school stays closed to survive in the old tradition, the santri will further fall behind in their future. In my opinion, the quality of formal education can produce young generation who master the Science of Technology and Faith and Taqwa". As stated by the subject of KP3 who said that the applied management is the management of Islamic religious education which combines the salafiyah Islamic boarding school and education in general according to the times that are marked by the use of technology as its supporting means. In the digital era, advancing formal education in a boarding school is very important. Nowadays, humans not only master the knowledge of Islam but also have professional expertise in science. So Islamic religious knowledge and general science must be mastered to answer the challenges ahead.

The preparation of teaching staff in Islamic boarding schools is also a material for the advancement of formal education in salafiyah boarding schools. This is revealed by the subjects. KP3 said, "The way is by selecting educators who have good competency, master technology properly or not technologically illiterate, have a good attitude". Preparation of teaching staff at the Salafiyah Islamic boarding school is also prioritized, according to Subject KP1 that we always try wisely in selecting every prospective educator, ranging from certificate, field expertise, attitude, and teamwork. It is necessary in preparing qualified teaching staff so that it helps the progress of formal education in the digital age. c. evaluation function of management

The evaluation function has the aim to determine the level of success. The KP1 explains that it can be done by evaluating Islamic religious education, general science, and technology science according to the level of education of the students. The comprehensive evaluation is supported by the use of technology. The KP3 subject reveals, "Continuous evaluation can be conducted to find out its success. The form of evaluation is providing tasks and conducting examination practices".

Based on the management evaluation, the results are excellent. The subject of KP1 says, "The results can be accurate by implementing continuous evaluation because each stage of the evaluation is completed by an explanation so that the students can get a comprehensive understanding. The form is that the students can master the Science of Technology and Faith and Taqwa amid the rapid development of the times". The results of the management evaluation are also revealed by Subject KP3 that the evaluation is carried out gradually that intended to teach the students until they have a good understanding.

\section{External Stakeholders}

Based on purposive and snowball sampling techniques, there are 3 parents of students from 3 Salafiyah Islamic Boarding Schools, 3 communities around Salafiyah Islamic Boarding Schools, and 3 students in Salafiyah Islamic Boarding Schools. The subject of this research is the external stakeholders. The function of this interview is to find out the management of the Salafiyah Islamic boarding school and the progress of formal educational institutions in the digital age. Coding is given to external stakeholders. The coding of the 3 parents of the students is the WL1, WL2, and WL3 codes. The coding for 3 communities is MP1, MP2, and MP3. The coding for 3 students is SP1, SP2, and SP3.

There are impacts felt by the surrounding community. The MP1 said that the community 
creates more jobs along with the high demand of students for formal education, such as selling food, boarding houses, public lodging for students' parents. Besides, the subject of MP2 felt that their village is widely known, the economy increases, and get adequate children's education facilities. The same thing is felt by MP3 that he have easiness in choosing education for his child because the location is near to his home.

The parents also have excellent views towards the progress of the Salafiyah Islamic boarding school which has a formal educational institution. WL1 believes that the reason for sending their children is to have a lot of skills, namely Islamic religious science as the foundation of life, general science as a provision, and technology as a weapon to compete in his future life. A good opinion is also expressed by WL2, "I strongly agree with the idea of integrating the salafiyah Islamic boarding school tradition with formal education to face the digital era." The subject of WL3 also believes that Children must be equipped with religious knowledge and technology properly so they can face competition in the future.

The students at the Salafiyah Islamic boarding school also feel good progress with the existence of formal institutions in this digital age. SP1 said, "I am happy with the learning process because the teachers teach us using various media. The material taught can be comprehensive, both Islamic religious science, general science, and technology science ". It is strengthened by SP2 that they are happy because the exam is not only memorized but also practiced using the technology that had been taught. The SP3 subject also argues, "I feel that I can simultaneously study Islamic religious education with sophisticated technology. Studying general knowledge accompanied by a professional teacher and a good classroom ".

\section{The collaboration of all stakeholders}

The planning function has been implemented well by preparing facilities and infrastructure as well as more professional educators for the digital era. The methods and strategies to overcome obstacles are patience, confidence, and establishing good communication with educators, students' parent, the surrounding community, and also the government. Thus, the community gives good responses regarding the planning function. The implementation function can integrate the boarding school curriculum with the modern education curriculum. The students' parents are very supportive because it is the right way to have lots of skills for their children. The evaluation function is conducted by applying various sciences in the world and the hereafter to master science and technology as well as to master faith and piety. The students feel pleasure because the learning process is not only memorizing but also practicing using sophisticated technology.

In the discussion, external stakeholders will not abandon the Salafiyah Islamic boarding school though the existence of formal institutions in the digital age. That is because external stakeholders require formal education as a foundation of life and to compete for future life. Thus, internal stakeholders must have a good understanding of management so they are not abandoned by external stakeholders.

\section{Discussion}

\section{Internal Stakeholders}

There are three management function implemented by Salafiyah Islamic boarding school in advancing formal educational institutions, namely planning, implementation, and evaluation. The planning function has been implemented well. The main figures already feel that they have an understanding of good management in formal education and the scope of Islamic boarding schools. Besides, the main figures perform a good planning function within the scope of the formal institutions. The Islamic boarding school currently integrates the Islamic Boarding School curriculum with the modern education curriculum. In formal institutions, the leaders prepare competent teaching staff in their fields. According to Kabeyi, strategic planning and management is the way to go for organizations to prepare themselves to sustain and overcome competion in market places. It is important for all organizations in private sector, publicsector and nonprofit organizations. It is a process that begins with self-assessment and 
realization and then reorganization to compete in a business environment (Kabeyi, 2019). As well as the opinion of Baridam that planning means to determine the objectives of the organization, examination of the environment and forecasting changes and development of policies, procedures and necessary plans to help achieve the objectives in view of the changing environment (Jeseviciute\&Ufartiene, 2014).

The implementation function is conducted excellently by prioritizing each other's readiness and having joint discussions to overcome problems. Islamic boarding schools have obstacles in preparing facilities and infrastructure as well as more professional teaching staff for the future era. Despite these obstacles, Salafiyah Islamic boarding schools that have formal institutions are ready for the digital era at this time. The methods and strategies to overcome obstacles are patience, confidence, and establishing good communication with educators, students' parent, the surrounding community, and also the government. According to Alharthy, formation and execution would shape the overall success or failure of an organization, and they change almost the whole dynamics of the organisation. Therefore, it is vital to design and implement the strategy from the top down and bottom up within the entire organisation. A core success pillar is to have a complete analysis done during the design stage first to secure the correct implementation of the strategy later (Alharthy et al, 2017). As well as the opinion of Faludi that The major essence of planning is its implementation aspect. This crucial component of planning can only be achieved or made possible when broad goals and definite objectives are translated into executable strategies. Plan implementation and its management do not only rest on the shoulders of planners but also other important actors and organizations such as community members, sub-structures such as Unit committees, Zonal and Area Councils, departments and units under the Assembly's structure (Abubakari et al, 2016).

The evaluation function is carried out by giving various problems to solve through several programs. It has the aim of mastering science, technology, faith, and piety. According to Harjanti, Evaluation is a systematic and objective assessment process carried out on activities, projects, programs, strategies, policies, topics, themes, sectors, regions or operational institutions. As an important part of the policy development process, evaluation provides an accountable and accurate assessment of the relevance, efficiency, effectiveness, impact, and sustainability of the intervention of a program. Evaluation is basically used to answer various questions about the program being evaluated, for example; whether stakeholders have done the right thing or is there a better way to achieve maximum results from a program (Harjanti et al, 2019).

\section{External Stakeholders}

The existence of formal education in Salafiyah Islamic boarding schools has an impact on external stakeholders. The community feels a good impact related to the existence of formal education. The economy is getting better with many creating jobs such as selling food, boarding houses, public lodging for students' parents. Besides, the community is interested in persuading their children to take this formal education because it will increase knowledge, not only religious knowledge but also technology science and so forth.

The management that has been carried out by the main figures in each of the salafiyah Islamic boarding schools is considered good by external stakeholders including the students' parents. The parents assess that sending their children to school is the right way to develop many skills, namely Islamic religion as the foundation of life, general science as a provision of life, and technology as a weapon to compete in this current era.

External stakeholders who directly feel the progress is the students at the Salafiyah Islamic boarding school. The students also state that the evaluation conducted by salafiyah boarding school management at the formal institution is excellent. The students are happy with the exam which not only memorized but also practiced using Islamic religious education with sophisticated technology. According to Pesqueux, 
Stakeholders can be "all agents (representatives), who can influence or become influenced when implementing organization's objectives" and" any individual or a group, which can influence or can be influenced when implementing organization's objectives" (Labanauskis\&Ginevičius, 2017).

\section{The collaboration of all stakeholders}

The planning function has been implemented well by preparing facilities and infrastructure as well as more professional educators for the digital era. The methods and strategies to overcome obstacles are patience, confidence, and establishing good communication with educators, students' parent, the surrounding community, and also the government. Thus, the community gives good responses regarding the planning function.

The implementation function can integrate the boarding school curriculum with the modern education curriculum. The students' parents are very supportive because it is the right way to have lots of skills for their children. The evaluation function is conducted by applying various sciences in the world and the hereafter to master science and technology as well as to master faith and piety. The students feel pleasure because the learning process is not only memorizing but also practicing using sophisticated technology.

In the discussion, external stakeholders will not abandon the Salafiyah Islamic boarding school though the existence of formal institutions in the digital age. That is because external stakeholders require formal education as a foundation of life and to compete for future life. Thus, internal stakeholders must have a good understanding of management so they are not abandoned by external stakeholders. According to ulewicz, students can be viewed as external stakeholders from enrolment perspective. However, they can be viewed as internal stakeholders as they have impact on the scholarly work done in the university. In order to achieve success, the aims of internal stakeholders, the first degree environment, ought to be compatible with the aims of external stakeholders (the second degree environment) (Savga et al, 2018).

\section{Conclusion}

The planning function has been implemented well by preparing facilities and infrastructure as well as more professional educators for the digital era. The implementation function can integrate the boarding school curriculum with the modern education curriculum. The evaluation function is conducted by applying various sciences in the world and the hereafter to master science and technology as well as to master faith and piety.

The existence of formal institutions in Salafiyah Islamic boarding schools encourages the main figures to develop a good management system. Moreover, the main character should approach external stakeholders. The approach can be in the form of good communication, motivating, availability of facilities, and infrastructure. The role of the main figures is crucial because they understand the weaknesses or strengths that have already occurred. Excellent management skills will not abandon the cultural tradition of salafiyah boarding school. It should go along with the formal institutions. The existence of salafiyah boarding schools and formal institutions will have a significant influence on religious thought and also academics.

The main figure of the Salafiyah Islamic boarding school must understand external stakeholders so that they are not left behind. Therefore, the main figures must be able to develop good management skills in each boarding school with formal institutions. They should be able to approach the government and surrounding communities. The external stakeholders also have the main goal, namely increasing education knowledge to reach a sustainable life. Thus, salafiyah Islamic boarding schools that do not have formal institutions will be better if they have formal institutions so that external stakeholders do not leave them behind.

\section{References}

[1] Abubakari, M., Asokwah, G., Dapaah, J. M., \& Appiah, S. C. Y. (2016). A review of plan implementation management practices in the bekwai municipality in the ashanti region of ghana. Current Urban Studies, 4, 146-156. 
[2] Alharthy, A.H., Rashid, H., Pagliari, R., \& Khan, F. (2017). Identification of strategy implementation influencing factors and their effects on the performance. International Journal of Business and Social Science, 8(1), 34-44.

[3] Behaghel, L., de Chaisemartin, C., \& Gurgaon, M. (2017). Ready for boarding? the effects of a boarding school for disadvantaged students. American Economic Journal: Applied Economics, 9(1), 140-164.

[4] Budiyono. (2017). Introduction to educational research methodologies. Surakarta: UNS Press.

[5] Fatmawati, E. (2018). Integration of islamic boarding school and university: typology study and curriculum of islamic boarding school university. International Journal of Management and Administrative Sciences (IJMAS), 5(10), 1-17.

[6] Fuadah, F.S., \& Sanusi, H.P. (2017). Learning management in islamic boarding school. Journal of Islamic Education Management, 2(2), 40-58.

[7] Gama, U.G. (2010). A survey of records management practices in circular primary schools in the metropolitan local government area (MLGas) of Kano State. Samaru Journal of Information Studies, 10 (1-2), 23-30.

[8] Gay, L.R. (1987). Educational research: competencies for analysis and application (Third Edition). Colombus Toronto, London, and Melbourne: Merril Publishing Company.

[9] Golnar, M. (2003). Khatami, political reform and education in Iran. Comparative Education. Routledge: Harvard Library, 39(3), 311-329.

[10] Harjanti, R., Supriyati, Y., \& Rahayu, W. (2019). Evaluation of learning programs at elementary school level of "Sekolah Alam Indonesia (SAI)". (Evaluative research using countenance stake's model). American Journal of Educational Research, 7(2), 125132.

[11] Hole, Y., \& Snehal, P. \& Bhaskar, M. (2018). Service marketing and quality strategies.
Periodicals of engineering and natural sciences, 6 (1), 182-196.

[12] Hole, Y., \& Snehal, P. \& Bhaskar, M. (2019). Porter's five forces model: gives you a competitive advantage. Journal of Advanced Research in Dynamical and Control System, 11 (4), 1436-1448.

[13] Jeseviciute, L. \& Ufartiene. (2014). Importance of planning in management developing organization. Journal of Advanced Management Science, 2(3), 176180.

[14] Kabeyi， M.J.B. (2019). Organizational strategic planning, implementation and evaluation with analysis of challenges and benefits for profit and nonprofit organizations. International Journal of Applied Research, 5(6), 27-32.

[15] Labanauskis, R., \& Ginevičius, R. (2017). Role of stakeholders leading to development of higher education services. Engineering Management in Production and Services, 9(3), 63-75.

[16] Latif, H.A. (2019). Needs analysis of english for specific purposes on islamic boarding school students. Voices of the English Language Education Society, 3(2), 136-144.

[17] Nilan, P. (2009). The 'spirit of education' in Indonesian pesantren. British Journal of Sociology of Education, 30(2), 219-232.

[18] Qolfathiriyus, A., Sujadi, I., \& Indriati, D. (2019). Characteristic profile of analytical thinking in mathematics problem solving. International Conference on Mathematics and Science Education. March. IOP Conf. Series: Journal of Physics: Conf. Series 1157 (2019) 032123, 1-6.

[19] Rafidah, Y., Ramly, M., Bunyamin, A., \& Halim, M.A. (2019). Kiai leadership style on internalization of character values of santri at islamic boarding school as'adiyah sengkang and darud dakwah. International Journal of Social Sciences, 74(1), 37-55.

[20] Stiawan, K., \& Tohirin, M. (2015). Format of salafi islamic boarding school along with social change in magelang city. Cakrawala, 10(2), 194-209. 
[21] Sukardi, I. (2016). Character education based on religious values: an islamic perspective. Ta'dib: Journal of Islamic Education, 21(1), 41-57.

[22] Salahuddin, M. (2017). Repositioning and existence of salafiyah madrasas in the global era. Scholar, 11(2), 215-232.

[23] Savga, L., Krykliy, O., \& Kyrychenko, K. (2018). The role of internal and external stakeholders in higher education system in ukraine. Business Ethics and Leadership, 2(1), 32-43.

[24] Sugiyono. (2013). Educational research methods of quantitative, qualitative, and R\&D approaches. Bandung: Alfabeta.

[25] Sugiyono. (2016). Quantitative, qualitative, and R\&D research methods. Bandung: PT Alfabet.

[26] Sukirman, H. (2006). Educational administration and supervision. Yogyakarta: FIP UNY.

[27] Tarrago, F.R., \& Wilson, A.E. (2010). Education management challenges for the 21 st century. KCKS, IFIP AICT, International Federation for Information Processing 2010, 324, 389-400.

[28] Terry, G.R. (2009). Principles of management, (Translation from J. Smith D. F. M.). Jakarta: Earth Literacy.

[29] Van Bruinessen, M. (1995). Shari’a court, tarekat, and pesantren: religious institutions in the Sultanate of Banten. Archipelago, 50, 165-199.

[30] Wang, S. \& Mao, Y. (2018). The effect of boarding on campus on left behind children sense of school belonging and academic achievement: Chinese evidence from propensity score matching analysis. Asia Pacific Journal of Education. Routledge: Taylor \& Francis Group, 38(3), 1-16.

[31] Yogesh Hole et al 2019 J. Phys.: Conf. Ser. 1362012121 